DOI: https://doi.org/10.24127/ajpm.v10i2.3586

\title{
ANALISIS KESULITAN BELAJAR MATEMATIKA SISWA MATERI BANGUN DATAR SEKOLAH MENENGAH PERTAMA
}

\author{
Edy Waluyo ${ }^{*}$, Nuraini \\ $1^{*}, 2$ Universitas Hamzanwadi, Selong, NTB, Indonesia \\ *Corresponding author. Universitas Hamzanwadi, 83612, NTB, Indonesia \\ E-mail : edywaluyo@hamzanwadi.ac.id ${ }^{\left.{ }^{*}\right)}$ \\ nurnuraeni@hamzanwadi.ac.id ${ }^{2)}$
}

Received 25 February 2021; Received in revised form 14 June 2021; Accepted 28 July 2021

\begin{abstract}
Abstrak
Penelitian ini bertujuan untuk menganalisis kesulitan belajar pada materi bangun datar siswa kelas VII SMPN 1 Suralaga Lombok Timur. Jenis penelitian ini merupakan penelitian deskriptif dengan pendekatan kualitatif untuk mendeskripsikan dan menggambarkan fenomena-fenomena dengan memperhatikan karakteristik, kualitas dan keterkaitan antar kegiatan. Pengumpulan data dilakukan dengan cara (1) Siswa diminta untuk menyelesaikan tes uraian tentang keliling dan luas bangun datar yang berjumlah 5 soal pada lembar jawaban yang sudah disiapkan; (2) mengambil beberapa jawaban siswa yang mengalami kesulitan untuk di analisis. Analisis data dilakukan melalui tahapan (1) mengidentifikasi dan mengelompokkan kesalahan kesalahan siswa dalam menjawab soal tentang bangun datar, (2) Menganalisis kesalahan kesalahan siswa. Subjek penelitian ini adalah siswa kelas VII SMPN 1 Suralaga yang berjumlah 25 orang. Instrumen penelitian yang digunakan adalah tes uraian tentang materi bangun datar. Hasil peneliti menunjukkan bahwa persentase jumlah siswa yang menjawab benar masih rendah. Dari 5 soal yang harus diselesaikan, persentase jumlah siswa yang menjawab benar soal berturut turut sebesar 48\%, 32\%, 44\%, $35 \%$ dan 40\%. Hasil analisis menunjukkan bahwa siswa mengalami kesulitan dalam menyelesaikan soal bangun datar, meliputi (1) kesulitan dalam penggunaan konsep, (2) kesulitan dalam penggunaan prinsip, (3) kesulitan pemecahan masalah.
\end{abstract}

Kata kunci: analisis; bangun datar; kesulitan

\begin{abstract}
This study aims to analyze the learning difficulties of planes materials of grade VII SMPN 1 Suralaga East Lombok. This type of research is descriptive research with qualitative approach to describe and describe phenomena by paying attention to characteristics, quality and interrelationship between activities. Data analysis is conducted through the stages (1) identifying and grouping student errors in answering questions about flat wakeups, (2) Analyzing student error errors. The subject of this study was a grade VII student of SMPN 1 Suralaga who numbered 25 people. The research instrument used is a description test of planes material. The researchers showed that the percentage of students who answered correctly was still low. The 5 questions that must be completed, the percentage of students who answered the correct questions in a row was 48\%, 32\%, 44\%, 35\% and 40\%. The results of the analysis showed that students had difficulty in solving flat wake problems, including (1) difficulties in the use of concepts, (2) difficulties in the use of principles, (3) difficulty solving problems
\end{abstract}

Keywords: analysis ; difficulty; planes

This is an open access article under the Creative Commons Attribution 4.0 International License

\section{PENDAHULUAN}

Perkembangan ilmu pengetahuan dan teknologi abad 21 saat ini telah mengubah karakteristik peserta didik sehingga memerlukan orientasi dan cara pembelajaran yang inovatif. Perlu dilakukan pembelajaran sedemikian sehingga setiap peserta didik mampu 
memiliki kemampuan berpikir tingkat tinggi, kemampuan memecahkan masalah, kemampuan berkomunikasi, dan kemampuan berpikir matematis untuk dapat menghadapi tantangan global (NCTM, 2000). Survei PISA tahun 2018 menunjukkan bahwa Indonesia hanya menduduki peringkat 72 dari 78 negara peserta (OECD, 2019).

Hasil TIMSS tahun 2015, menyatakan bahwa hasil belajar matematika siswa Indonesia berada pada urutan ke-44 dari 49 negara dengan rata-rata skor 397 (Mullis, et al, 2016). Hal ini menunjukkan bahwa dalam pembelajaran jarang membiasakan siswa untuk menggunakan kemampuan berpikir tingkat tinggi dalam menghadapi dan menyelesaikan masalah nyata dikehidupan sehari hari (Yanti, 2019). Nur \& Palobo (2018) menyatakan bahwa 75,7 \% siswa Indonesia memiliki kinerja yang rendah dan hanya mampu mengerjakkan soal yang sederhana, dan hanya $0,1 \%$ siswa yang mampu menyelesikan pemodelan matematika yang menuntut keterampilan berpikir dan pemecahan masalah.

Untuk mengatasi persoalan tersebut dapat dilakukan proses pembelajaran demikian sehingga terjadi proses strukturisasi aktivitas pembelajaran yang melibatkan siswa dalam menyelesaikan permasalahan yang diberikan yang pada akhirnya siswa dapat memilih cara yang tepat dalam memecahkan persoalan matematika yang dihadapinya (Khaulah, 2018).

Dalam berpikir tingkat tinggi, peserta didik dituntut untuk menggali ide, wawasan dan gagasan baru untuk menyelesaikan permasalahan yang dihadapi, sehingga dalam proses pembelajaran dikelas, guru dituntut untuk dapat merancang pembelajaran yang mampu melatih dan mengembangkan kemampuan berpikir tingkat tinggi peserta didik.

Berpikir tingkat tinggi meliputi kemampuan berpikir kritis, logis, reflektif, metakognitif, dan kreatif (Fanani \& Kusmaharti, 2014). Berpikir tingkat tinggi adalah berpikir pada tingkat lebih tinggi dari pada sekedar menghafal fakta atau mengatakan suatu informasi kepada seseorang (Heong et al., 2011). Usaha untuk meningkatkan kemampuan berpikir tingkat tinggi peserta didik dapat dilakukan melalui perbaikan pembelajaran yang berpusat pada siswa karena melalui perbaikan pembelajaran ini keterampilan 4C siswa yaitu creativity, critical thinking, collaboration dan communication siswa dapat dikembangkan.

Siswa tidak semuanya berhasil dalam melakukan kegiatan belajar, terkadang juga mengalami hambatanhambatan yang mengakibatkan kegagalan belajar. Siswa berkesulitan belajar sering melakukan kekeliruan dalam belajar berhitung, belajar geometri, dan kekeliruan dalam menyelesaikan soal cerita (Utari, et al., 2019). Hasibuan (2018) menyatakan bahwa kesulitan belajar adalah salah satu faktor eksternal siswa yang mengakibatkan rendahnya prestasi belajar siswa, sehingga siswa yang bersangkutan sulit melakukan kegiatan belajar secara efektif.

Kesulitan belajar matematika siswa disebabkan karena kesulitannya dalam membentuk kontruksi nyata yang akurat, membutuhkan ketelitian dalam pengukuran, membutuhkan waktu yang lama dan bahkan banyak siswa yang mengalami hambatan dalam pembuktian terhadap jawabannya (Noto et al, 2019). Mufarizuddin (2018) mengatakan bahwa kesulitan siswa 
meliputi kesulitan siswa dalam keterampilan, kesulitan dalam memahami konsep dan kesulitan dalam pemecahan masalah matematika. Dalam pembelajaran, diharapkan guru mampu membuat siswa memahami dan mengerti serta menguasai konsepkonsepyang ada secara baik, dan benar serta siswa tidak mengalami kesulitan apabila konsep sudah tertanam dan dipahami dengan baik oleh siswa.

Penelitian tentang analisis kesulitan belajar matematika siswa materi bangun ruang pernah dilakukan diantaranya oleh (Awwalin,2021; Fauzi, 2020; Khoirunnisa, 2020; Sumiati, 2020; Simbolon, 2019; Hidajat, 2018) secara umum menyatakan bahwa siswa mengalami kesulitan dalam menyelesaikan soal soal geometri yang berkaitan dengan bangun datar dan ruang. Yang membedakan dengan penelitian yang saya lakukan adalah pada penelitian sebelumnya kesulitan yang dianalisis meliputi kesulitan dalam pemahaman konsep dan kesulitan dalam memahami simbol simbol geometri, sedangkan penelitian ini disamping menganalisis kesulitan dalam pemahaman konsep juga dilakukan analisis terhadap kesulitan dalam menggunakan prinsip dan pemecahan masalah.

Beberapa kesulitan siswa dalam belajar matematika adalah : (1) kesulitan dalam membedakan angka, simbol-simbol, dan bangun ruang, (2) tidak sanggup untuk mengingat dalildalil pada matematika, (3) menulis angka tidak terbaca atau dalam ukuran kecil, (4) pemahaman siswa akan simbol-simbol matematika,

kemampuan berpikir abstrak siswa lemah, (6) lemahnya kemampuan siswa dalam mengidentifikasi dan dalam memanfaatkan algoritma dalam memecahkan soal-soal matematika
(Ekawati \& Saragih, 2018). Kesulitan belajar matematika diklasifikasikan ke dalam tiga jenis diantaranya adalah (1) kesulitan siswa dalam penggunaan konsep, (2) kesulitan siswa dalam penggunaan prinsip, (3) kesulitan siswa dalam menyelesaikan masalah masalah verbal (Yusmin, 2017).

Pentingnya pemahaman konsep dalam matematika khususnya pada materi bangun datar dan kesulitan yang dihadapi siswa, perlu dilakukan pengkajian tentang kesulitan belajar matematika khususnya pada materi bangun datar. Hal ini perlu dilakukan agar guru mengetahui letak dan jenis kesulitan yang dialami siswa dalam pembelajaran bangun datar sehingga guru dapat mengatasi kesalahan kesalahan yang dilakukan siswa dalam menyelesaikan soa soal bangun datar. Oleh karena itu, penelitian ini bertujuan untuk menganalisis dan mendeskripsikan kesulitan belajar matematika siswa pada materi bangun datar.

\section{METODE PENELITIAN}

Jenis penelitian ini merupakan penelitian deskriptif dengan pendekatan kualitatif. Pemilihan pendekatan ini dimaksudkan karena peneliti ingin mendeskripsikan dan menggambarkan fenomena fenomena yang ada, yang lebih memperhatikan mengenai karakteristik, kualitas dan keterkaitan antar kegiatan. Disamping itu, peneliti juga ingin mengeksplorasi dan memahami makna yang oleh sejumlah individu atau sekelompok orang dianggap berasal dari sosial. Dengan demikian, pendekatan kualitatif ini sangat cocok digunakan dalam mengungkap berbagai fenomena sentra yang muncul dalam penelitian ini. Langkah-langkah penelitian ini yaitu (1) Siswa secara individu diminta untuk 
menjawab soal tes uraian tentang bangun datar atar dalam waktu 45 menit (2) Pengerjaan siswa pada lembar jawaban yang disiapkan merupakan data pendukung hasil tes siswa, (3) peneliti melakukan wawancara terhahap beberapa siswa yang mengalami kesulitan.

Subjek penelitian ini adalah siswa kelas VII SMPN 1 Suralaga yang berjumlah 25 orang dengan teknik nonprobability samping, dimana subyek dianggap mewakili kelompok normal dari fenomena yang diteliti. Instrumen penelitian yang digunakan adalah tes uraian tentang konsep bangun datar dengan indikator : (a) menghitung luas dan keliling bangun datar; (2) menyelesaikan masalah dalam kehidupan sehari-hari dengan menggunakan sifat-sifat bangun datar; (3) Menyelesaikan soal penerapan bangun datar.

Pengumpulan data dilakukan dengan cara (1) Siswa diminta untuk menyelesaikan tes uraian tentang keliling dan luas bangun datar yang berjumlah 5 soal pada lembar jawaban yang sudah disiapkan; (2) mengambil secara jawaban siswa yang mengalami kesulitan untuk di analisis dan selanjutnya dilakukan wawancara.

Analisis data dilakukan melalui tahapan (1) mengidentifikasi dan mengelompokkan kesalahan kesalahan siswa dalam menjawab soal tentang bangun datar, (2) Menganalisis kesalahan kesalahan siswa, (3) Triangulasi data, yaitu mensintesa data yang sudah terkumpul dari berbagai sumber. Analisis kesulitan belajar geometri pada materi bidang datar didasarkan pada kemampuan siswa dalam penggunaan konsep, penggunaan prinsip dan kemampuan pemecahan masalah. Penggunaan konsep merupakan kemampuan mendasar dalam belajar matematika yaitu kemampuan dalam menjelaskan keterkaitan antar konsep dan mengaplikasikan konsep atau algoritma secara luwes, akurat, efisien, dan tepat dalam pemecahan masalah (Sumiati, 2020). Penggunaan prinsip dalam matematika merupakan penerapan dari dua atau lebih konsep dalam matematika meliputi kegiatan penemuan, mencari faktor yang relevan, dan menyimpulkan sebuah arti sampai menerapkan sesuatu yang mereka temukan. Sedangkan kemampuan pemecahan masalah merupakan kemampuan dimana siswa dituntut untuk berpikir secara sistematis, kritis, dan logis untuk menemukan penyelesaian dari masalah matematika yang dihadapi. Pemecahan masalah sebagai suatu keterampilan individu merupakan proses dalam menganalisis, menafsirkan, menalar, memprediksi, mengevaluasi, dan merefleksikan dari permasalahan yang akan diselesaikan (Waluyo, 2021).

\section{HASIL DAN PEMBAHASAN}

Penelitian dilakukan untuk memperoleh hasil analisis kesulitan siswa dalam menjawab soal materi statistika berupa tes kepada subjek penelitian berjumah 25 siswa. Data hasil penelitian yang dikumpulkan berupa skor kemampuan siswa dalam menyelesaiakan soal bangun datar. Skor hasil belajar siswa tentang bangun datar disajikan dalam tabel 1.

Berdasarkan Tabel 1, persentase siswa yang menjawab tes dengan benar tentang bangun datar masih rendah. Dari 5 soal yang harus diselesaikan, rata rata persentase siswa yang menjawab benar sebesar $40 \%$ masih dibawak kriteria ketuntasan minimal yang ditetapkan guru sebesar $75 \%$. 
DOI: https://doi.org/10.24127/ajpm.v10i2.3586

Tabel 1. Skor tes siswa tentang bangun datar.

\begin{tabular}{cccc}
\hline Soal & \multicolumn{2}{c}{$\begin{array}{c}\text { Jumlah siswa } \\
\text { menjawab }\end{array}$} & Persentase \\
\cline { 2 - 3 } & Benar & Salah & \\
\hline 1 & 12 & 13 & $48 \%$ \\
2 & 8 & 17 & $32 \%$ \\
3 & 11 & 14 & $44 \%$ \\
4 & 9 & 16 & $36 \%$ \\
5 & 10 & 15 & $40 \%$ \\
\hline Rerata & 50 & 75 & $40 \%$ \\
\hline
\end{tabular}

Dari lembar jawaban siswa, terdapat beberapa kesalahan yang dilakukan siswa, yang dilatar belakangi oleh kesulitan siswa dalam mengerjakan soal bangun datar. Jenis kesulitan yang dialami siswa dalam menyelesaikan soal bangun datar meliputi kesulitan : (1) kesulitan dalam pemahaman konsep; (2) kesulitan dalam penggunaan prinsip; (3) kesulitan dalam pemecahan masalah.

\section{Kesulitan Pemahaman Konsep}

Pemahaman konsep merupakan kemampuan pertama yang diharapkan dapat tercapai dalam tujuan pembelajaran matematika (Ningsih, 2016). Pemahaman konsep sangat penting dikuasai siswa dalam menyelesaikan berbagai bentuk soal dalam matematika. Pemahaman dan penggunaan konsep dalam matematika terkait dengan bagaimana memahami dan membedakan kata, simbol dan tanda (Novitasari, 2016).

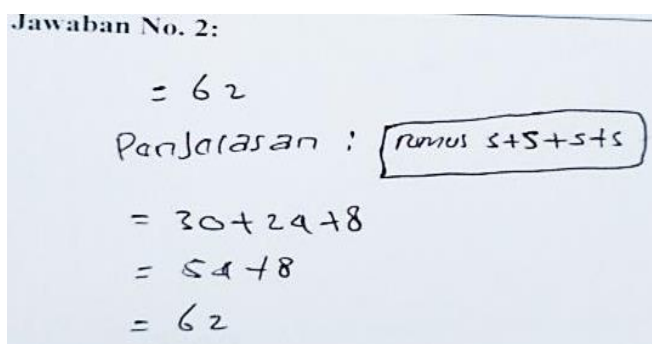

Gambar 1. Kesulitan dalam konsep subyek $\mathrm{S}-2$

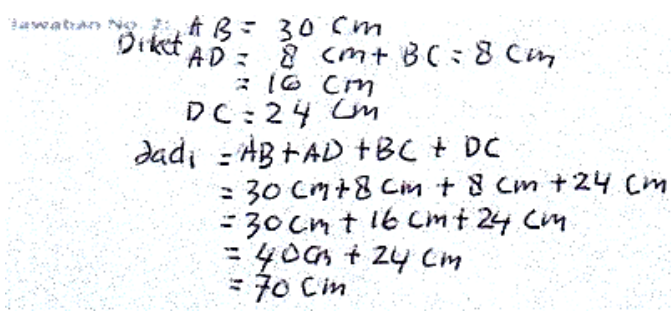

Gambar 2. Kesulitan dalam Konsep subyek S-8

Berdasarkan jawaban siswa terhadap soal soal bangun datar yang diberikan, kesalahan konsep yang dilakukan siswa disajikan seperti Gambar 1. Berdasarkan Gambar 1 dan 2 kesulitan yang dialami S-2 dan S-8 dalam menjawab soal nomor 2 adalah kesulitan dalam kemahaman konsep. Karena siswa S-2 dan S-8 menggunakan urutan konsep yang salah, seharusnya menggunakan rumus teorema phytagoras untuk mencari panjang sisi miring atau CB. Kemudian selanjutnya menggunakan rumus keliling trapesium untuk menentukan keliling trapesium. Akan tetapi, siswa S-2 langsung menggunakan rumus keliling atau menjumlahkan seluruh sisi yang diketahui tanpa mencari berapa panjang sisi CB. Siswa juga tidak menjelaskan apa saja yang diketahui dan ditanyakan oleh soal. Sedangkan untuk S-8 mengira bahwa panjang sisi miring atau BC sama dengan $\mathrm{AD}$, sehingga ia langsung mencari keliling dari trapesium tersebut. Seharusnya siswa mencari BC dengan menggunakan rumus phytagoras. Karena kekeliruan tersebut siswa S-2 dan S-8 salah dalam menentukan hasil akhir. Hal ini sejalan dengan penelitian yang dilakukan oleh Fauzi \& Arisetyawan, (2020) yang menyebutkan bahwa siswa mengalami kesulitan dalam memahami sebuah konsep dari keliling, kesulitan dalam penggunaan rumus atau cara dalam mencari keliling bangun datar. Begitu pula penelitian yang dlakukan oleh Awwalin (2021) 
DOI: https://doi.org/10.24127/ajpm.v10i2.3586

\begin{abstract}
menunjukkan bahwa siswa masih mengalami kesulitan dalam menyelesaikan soal mengenai materi bangun ruang sisi datar. Kebanyakan siswa kurang mampu menyelesaikan soal mengenai luas, volume dari balok dan prisma. Siswa tidak memahami dengan benar apa yang ditanyakan pada soal, siswa tidak menguasai rumus luas dan volume dari balok dan prisma.
\end{abstract}

\section{Kesulitan dalam Penggunaan Prinsip}

$\begin{array}{lcr}\text { Penggunaan } & \begin{array}{r}\text { prinsip } \\ \text { merujuk }\end{array} & \begin{array}{r}\text { dalam } \\ \text { kepada }\end{array} \\ \text { kematematika } & \text { siswa } & \text { untuk }\end{array}$ menghubungkan dua konsep atau lebih dalam matematika dengan gagasan yang mereka ketahui, untuk menggambarkan situasi matematika dalam cara-cara yang berbeda (Fatma, 2017). Siswa dikatakan memahami konsep jika siswa mampu mendefinisikan konsep, mengidentifikasi dan memberi contoh atau bukan contoh dari konsep, mengembangkan kemampuan koneksi matematik antar berbagai ide, memahami bagaimana ide-ide matematik saling terkait satu sama lain sehingga terbangun pemahaman menyeluruh, dan menggunakan matematik dalam konteks di luar matematika (Aningsih, Asih, 2017). Dengan demikian untuk menyelesaikan soal soal matematika yang berhubungan dengan prinsip maka siswa harus menguasai konsep konsep terlebih dahulu. Contoh kesalahan penggunaan prinsip yang dilakukan siswa dalam menyelesaikan soal matematika yang diberikan dalam penelitian ini disajikan seperti Gambar 3.

Berdasarkan Gambar 3, Gambar 4 dan Gambar 5, siswa S-9, S-11, S-12 mengalami kesulitan dalam penggunaan prinsip. Siswa dikatakan mengalami kesulitan dalam penggunaan prinsip apabila siswa melakukan kesalahan dalam menggunakan operasi dasar (penjumlahan, pengurangan, perkalian dan pembagian), serta menyelesaikan soal dengan langkah yang tidak tepat.

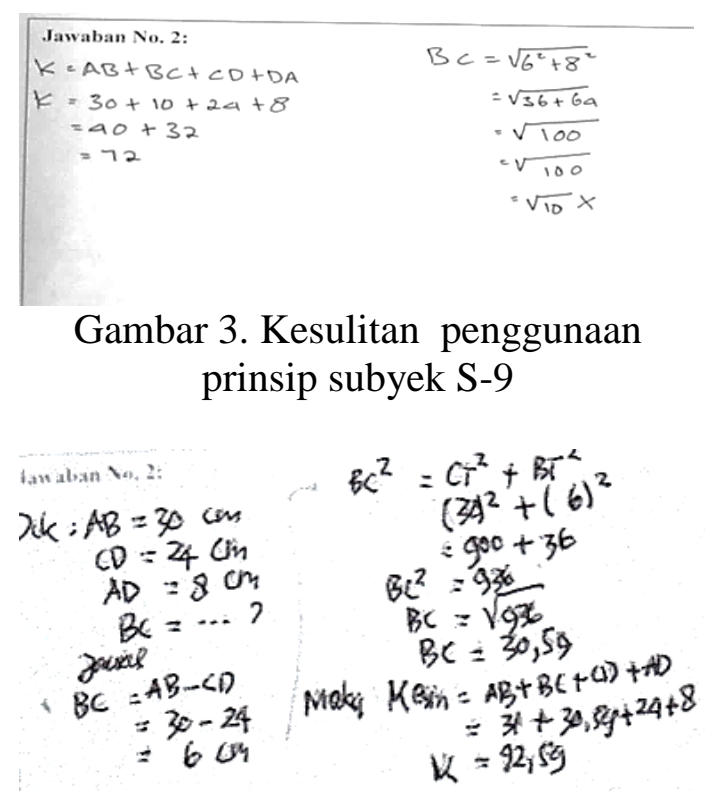

Gambar 4. Kesulitan penggunaan prinsip subyek S-11

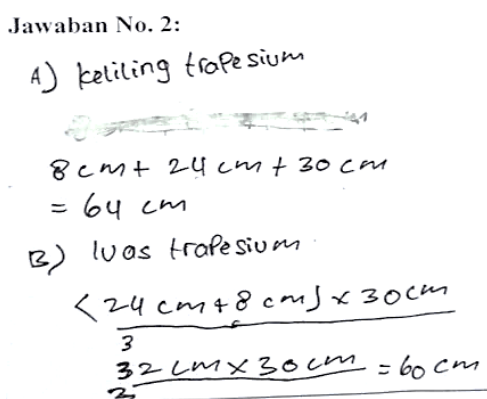

Gambar 5. Kesulitan penggunaan prinsip subyek S-12

Siswa S-9 tidak menjelaskan apa saja yang diketahui dan ditaanyakan dari soal yang ada. Siswa langsung menggunakan rumus teorema pythagoras. Namun hasil akhir dari jawaban S-9 sudah benar dalam pengoprasian rumus phythagoras tetapi sedikit keliru di nilai $\sqrt{100}=\sqrt{10}$ yang sehasusnya $\sqrt{100}=10$. Siswa sudah menggunakan rumus keliling trapesium dengan benar, tetapi S-9 juga tidak 
menarik kesimpulan setelah menemukan jawaban yang benar. Untuk siswa S-11 sudah menggunakan urutan konsep yang benar, tetapi ia keliru dalam pengoperasian rumus teorema pythagoras. Siswa mengira panjang sisi $C T=A B=30 \mathrm{~cm}$, yang sebenarnya panjang $C T=A D=8 \mathrm{~cm}$. Sehingga didapatkan panjang sisi miring $B C=$ $\sqrt{936}=30,59$ yang seharusnya adalah $B C=\sqrt{100}=10$. Kekeliruan pada pengoperasian teorema pythagoras maka hasil akhir yang didapatkan salah. Sedangkan untuk siswa S-11 menggunakan langkah penyelesaian yang tidak tepat. Siswa juga tidak menjelaskan apa saja yang diketahui dan ditanyakan oleh soal, tetapi siswa langsung menjumlahkan seluruh sisi yang diketahui tanpa panjang sisi miring BC. Siswa melakukan kesalahan dalam berhitung yang dimana $8 \mathrm{~cm}+$ $24 \mathrm{~cm}+30 \mathrm{~cm}=64 \mathrm{~cm} \quad$ yang seharusnya $62 \mathrm{~cm}$. Dari kesalahan dan perhitungan yang dilakukan sehingga $S$ 11 tidak mendapatkan hasil akhir yang benar. Penelitian ini sejalan dengan penelitian yang dilakukan oleh dalam Sholihah \& Afriansyah (2017) yang menyebutkan bahwa pemahami materi geometri siswa masih kesulitan dalam menerapkan rumus-rumus, memahami teorema-teorema, bahkan yang paling utama siswa masih mengalami kesulitan dalam memahami permasalahan dalam suatu soal.

\section{Kesulitan pemecahan Masalah}

Pemecahan masalah ialah aktivitas intelektual guna menemukan solusi penyelesaian dari masalah dengan melibatkan pengetahuan dan pengalaman (Maimunah, et al, 2016). Pemecahan masalah sebagai suatu kemampuan dalam mempergunakan pengetahuan yang sebelumnya telah diketahui pada situasi baru untuk menyelesaikan masalah (Ulya, 2016). Kesulitan siswa yang berkaitan dengan masalah verbal, sering muncul disebabkan karena ketidakmampuan siswa dalam menggunakan konsep dan prinsip matematika (Abrar, 2018). Berdasarkan analisis jawaban siswa, kesulitan dalam melakukan pemecahan masalah yang dilakukan siswa diantaranya seperti disajikan dalam Gambar 6.

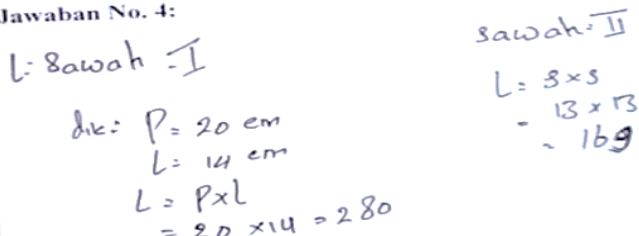

Gambar 6. Kesulitan pemecahan masalah subyek S-9

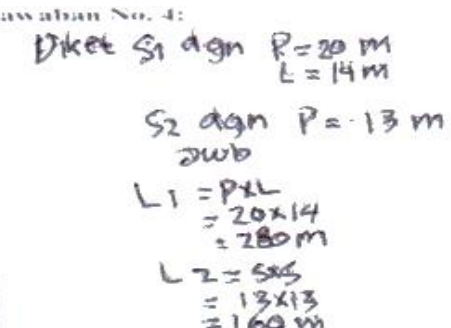

Gambar 7. Kesulitan pemecahan masalah subyek S-1

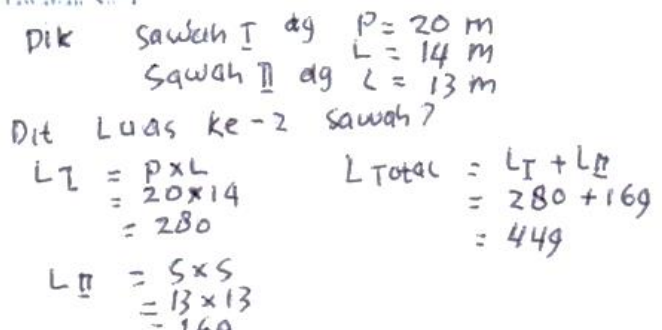

Gambar 8. Kesulitan pemecahan masalah subyek S-3

Berdasarkan Gambar 6, Gambar 7 dan Gambar 8 kesulitan yang dialami siswa S-9, S-1 dan S-3 adalah kesulitan dalam pemecahan masalah dan tidak membuat kesimpulan setelah menemukan jawaban yang benar. Hal ini karena kurangnya kemampuan atau pengetahuan tentang strategi yang 
digunakan dalam menyelesaikan soal. Subyek S-9 dan S-1 tidak tahu apa yang harus dilakukan selanjutnya. Sedangkan subyek S-9 juga tidak menjelaskan apa yang diketahui dan ditanyakan dari soal yang ada siswa langsung mencari luas masing-masing sawah selain itu siswa juga tidak menulis satuan luas dan itu memiliki arti yang berbeda. Subyek S-1 menjelaskan apa yang diketahui tetapi tidak menjelaskan apa yang ditanyakan dari soal yang ada siswa langsung mencari luas masing-masing sawah, selain itu siswa juga salah dalam menulis satuan luas sawah dalam $(\mathrm{m})$ yang seharusnya dalam $\left(\mathrm{m}^{2}\right)$ dan itu memiliki arti yang berbeda. Setelah menemukan luas dari masing-masing sawah, siswa tidak bisa melanjutkan jawabannya hingga akhir. Seharusnya S-9 dan S-1 setelah mencari luas dari masing-masing sawah petani, langkah yang selanjutnya dilakukan adalah mencari berapa luas kedua sawah petani, dengan menjumlahkan $L_{1}+L_{2}$ dan akan mendapatkan hasil akhir dari luas kedua sawah petani adalah $449 \mathrm{~m}^{2}$. Sedangkan S-3 sudah menggunakan rumus yang benar dan urutan konsep yang tepat. Jawaban S-3 juga sudah benar namun S-3 tidak menarik kesimpulan setelah menemukan jawaban yang benar, siswa juga tidak menulis satuan dalam $\left(\mathrm{m}^{2}\right)$ hanya menulis 449 saja dan itu memiliki arti yang berbeda. Hal ini sejalan dengan penelitian yang dilakukan oleh Waluyo, (2021) yang menyatakan bahwa kemampuan pemecahan masalah matematika siswa masih rendah, dilihat dari latihan setelah belajar yang menunjukkan siswa hanya mampu menyelesaikan soal jika soal tersebut mempunyai bentuk yang sama seperti contoh yang sudah diberikan. Penelitian ini juga sejalan dengan penelitian yang dilakukan oleh Hidajat (2018) yang menyatakan bahwa siswa kesulitan dalam memahami perintah soal, kesulitan menentukan rumus yang digunakan, dan kesulitan menghitung dan menggunakan simbul. Sejalan juga dengan penelitian yang dilakukan oleh Fauzi (2020) yang menyatakan bahwa dalam memecahkan masalah geometri bangun datar siswa kesulitan dalam menggunakan rumus dan simbul, tidak menggunakan langkah penyelesaian masalah dengan benar. Kesulitan belajar ini akan berdampak pada rendahnya kemampuan pemecahan masalah matematika siswa khususnya pada materi bangun datar, dan pada akhirnya akan berdampak pada rendahnya hasil belajar matematika siswa secara umum.

\section{KESIMPULAN DAN SARAN}

Kesimpulan yang diperoleh berdasarkan hasil analisis data yang telah dilakukan adalah siswa mengalami kesulitan belajar pada materi bangun datar. Hasil analisis terhadap pekerjaan siswa ketika menyelesaikan soal yang diberikan, kesulitan yang dihadapi siswa antara lain adalah (1) kesulitan dalam penggunaan konsep, yaitu kesulitan dalam memaknai istilah dan rumus dalam bangun datar. (2) kesulitan dalam penggunaan prinsip. Dalam hal ini siswa kesulitan dalam memahami arti dari prinsip yang telah ditemukan dan tidak mampu menerapkan prinsip tersebut dan, (3) kesulitan dalam menyelesaikan masalah. Pada keadaan ini, siswa tidak mampu menggunakan konsep dan prinsip yang ditemukan untuk menyelesaikan soal tentang bangun datar.

Berdasarkan kesimpulan yang dipaparkan di atas, kesulitan yang dialami siswa ketika menyelesaikan soal geometri materi bangun datar perlu mendapatkan perhatian secara khusus 
bagi guru. Perlu dilakukan pembelajaran yang berpusat pada siswa dan mampu mengembangkan kemampuan berpikir tingkat tinggi sehingga siswa mampu memahami konsep dan prinsip prinsip tentang materi yang dibelajarkan serta mampu menyelesaikan permasalahan matematika yang dihadapi khususnya pada materi bangun datar.

\section{DAFTAR PUSTAKA}

Abrar, A. I. P. (2018). Kesulitan Siswa SMP Belajar Konsep Dan Prinsip Dalam Matematika. Al-Khwarizmi: Jurnal Pendidikan Matematika Dan Ilmu Pengetahuan Alam, 2(1), 59-68.

https://doi.org/10.24256/jpmipa.v2 i1.102

Aningsih, \& Asih, T. (2017). Analisis Kemampuan Pemahaman Konsep Matematika Ditinjau dari Rasa Ingin Tahu Siswa pada Model Concept Attainment. Unnes Journal of Mathematics Education Research, 6(2), 217-224. Retrieved from http://journal.unnes.ac.id/sju/index. php/ujmer\%0AAnalisis

Awwalin, A. (2021). Analisis Kesulitan Siswa SMP Kelas VIII Pada Materi Bangun Ruang Sisi Datar. JPMI: Jurnal Pembelajaran Matematika Inovatif, 4(1), 225230.

https://doi.org/10.22460/jpmi.v4i1. 225-230

Ekawati, \& Saragih, M. (2018). Kesulitan Belajar Matematika Berkaitan dengan Konsep pada Topik Aljabar. Journal of Language, Literature, Culture, and Education, 14(1), 53-64. http://dx.doi.org/10.19166/pji.v14i 1.453
Fanani, A., \& Kusmaharti. (2014). Pengembangan pembelajaran berbasis HOTS (Higher Order Thinking Skill) di Sekolah Dasar Kelas V. Jurnal Pendidikan Dasar, 9(1), 1-11. https://doi.org/10.21009/JPD.091.0 1

Fatma, E., \& Sare, S. (2017). The Effect of Cooperative Learning Method Enhanced with Metacognitive Strategies on Students' Metacognitive Skills in Math Course. Education and Science, 42(192), 263-301. https://doi.org/10.15390/EB.2017.6 492

Fauzi, I., \& Arisetyawan, A. (2020). Analisis Kesulitan Belajar Siswa pada Materi Geometri di Sekolah Dasar. Kreano: Jurnal Matematika Kreatif-Inovatif, 11(1), 27-35.

http://dx.doi.org/10.15294/kreano. v11i1.20726

Hasibuan. (2018). Analisis Kesulitan Belajar Matematika Siswa Pada Pokok Bahasan Bangun Ruang Sisi Datar Di Smp Negeri 12 Bandung. Axiom, $\quad \operatorname{VII}(1), \quad 18-30$. http://dx.doi.org/10.30821/axiom.v $7 \mathrm{i} 1.1766$

Heong, Y. M., Othman, W. B., Yunos, J., Kiong, T., Hassan, R., Mohaffyza, M., \& Mohamad, B. (2011). The Level of Marzano Higher Order Thinking Skills among Technical Education Students. International Journal of Social Science and Humanity, 1(2), 121-125.

https://doi.org/10.7763/IJSSH.201 1.V1.20

Hidajat, D., Pratiwi, A., \& Afghohani, A. (2018). Analisis Kesulitan Dalam Penyelesaian Permasalahan Ruang Dimensi Dua. Jurnal 
DOI: https://doi.org/10.24127/ajpm.v10i2.3586

Pendidikan Matematika, 1(1), 116.

http://dx.doi.org/10.21043/jpm.v1i 1.4452

Khaulah, S. (2018). Penerapan model pembelajaran jucama dengan menggunakan blok aljabar untuk meningkatkan kemampuan berfikir kreatif siswa pada materi persamaan kuadrat. Jurnal Pendidikan Almuslim, 6(2), 75-83. Retrieved from http://jfkip.umuslim.ac.id/index.ph $\mathrm{p} / \mathrm{jupa} /$ issue/view/52

Maimunah., Purwanto., Sa'dijah, C., \& Sisworo. (2016). Penerapan Model Pembelajaran Matematika Melalui Pemecahan Masalah untuk Meningkatkan Penalaran Matematis Siswa Kelas XA SMA Al-Musilum. Jurnal Review Pembelajaran Matematika, 1(1), 17-30.

https://doi.org/10.15642/jrpm.2016

Mufarizuddin. (2018). Analisis Kesulitan Pembelajaran Matematika Siswa Kelas V Sd Negeri 012 Bangkinang Kota. Journal on Education, 1(1), 40-47. https://doi.org/10.31004/joe.v1i1.8

Mullis, I. V. S., Martin, M. O., Foy, P., \& Hooper, M. (2016). TIMSS 2015 international results in Mathematics. Retrieved from Boston College, TIMSS \& PIRLS International Study Center. Retrieved from http://timssandpirls.bc.edu/timss20 15/international-results/

NCTM. (2000). Principles and Standards for School Mathematics. Retrieved from www.nctm.org

Ningsih, Y. (2016). Kemampuan Pemahaman Kon $\neg$ sep Matematika Mahasiswa Melalui Penerapan Lembar Aktivitas Mahasiswa (LAM) Berbasis Teori Apos Pada
Materi Turunan. 06(1), 1-8. https://doi.org/10.22437/edumatica .v6i01.2994

Noto, M. S., Priatna, N., \& Dahlan, J. (2019). Mathematical proof: The Learning Obstacles of Preservice Mathematics Teachers on Transformation Geometry. Journal on Mathematics Education, 10(1), 117-126.

https://doi.org/10.22342/jme.10.1.5 379.117-126

Novitasari, D. (2016). Pengaruh Penggunaan Multimedia Interaktif Terhadap Kemampuan Pemahaman Konsep Matematis Siswa. FIBONACCI: Jurnal Pendidikan Matematika Dan Matematika, 2(2), 8-18. https://doi.org/10.24853/fbc.2.2.818

Nur, A. S., \& Palobo, M. (2018). Profil Kemampuan Pemecahan Masalah Matematika Siswa Ditinjau dari Perbedaan Gaya Kognitif dan Gender. Kreano : Jurnal Matematika Kreatif- Inovatif, 9(2), 139-148.

https://doi.org/10.15294/kreano.v9i 2.15067

OECD. (2019). Multilingual Summaries PISA 2018 Results What Students Know and Can Do. I. Retrieved from

http://www.oecd.org/termsandcond itions.

Sholihah, S. Z., \& Afriansyah, E. (2017). Analisis Kesulitan Siswa dalam Proses Pemecahan Masalah Geometri Berdasarkan Tahapan Berfikir Van Hiele. Mosharafa, 6(2), 287-298. https://doi.org/10.31980/mosharafa .v6i2.317

Simbolon, H., \& Ramadhani, D. (2019). Analisis Kesulitan Belajar Matematika Materi Bangun Datar 
SD Negeri 7 Langsa. Journal of Basic Education Studies, 2(1), 100-111. Retrieved from https://ejurnalunsam.id/index.php/j bes/article/view/1594

Sumiati, A., \& Agustini, Y. (2020). Analisis Kesulitan Menyelesaikan Soal Segiempat dan Segitiga Siswa SMP Kelas VIII di Cianjur. Jurnal Cendekia: Jurnal Pendidikan Matematika, 4(1), 321-330. https://doi.org/10.31004/cendekia. v4i1.184

Syifa Khoirunnisa, Sulhan, Kalsum, Dorkas, L., \& Oktavianus. (2020). Analisis Sesulitan Siswa Dalam Menyelesaikan Soal Matematika Materi Luas Permukaan dan Volume Bangun Ruang Sisi Datar. Prismatika: Jurnal Pendidikan Dan Riset Matematika, 2(2), 2132.

https://doi.org/10.33503/prismatika .v2i2.740

Ulya. H. (2016). Profil Kemampuan Pemecahan Masalah Siswa Bermotivasi Belajar Tinggi Berdasarkan Ideal Problem Solving. Jurnal Konseling GUSJIGANG, 2(1), 90-96. https://doi.org/10.24176/jkg.v2i1.5 61

Utari, D. R., Wardana, M. Y. S., \& Damayani, A. T. (2019). Analisis Kesulitan Belajar Matematika dalam Menyelesaikan Soal Cerita. Jurnal Ilmiah Sekolah Dasar, 3(4), 534-540.

http://dx.doi.org/10.23887/jisd.v3i 4.22311 Article Metrics

Waluyo, E., \& Nuraini. (2021a). Development CPS Integrated TPACK Model to Improve Student Problem Solving In New Normal Pandemic Covid-19. Al-Jabar: Jurnal Pendidikan Matematika, 12(1), 133-146. https://doi.org/10.24042/ajpm.v12i 1.8600

Waluyo, E., \& Nuraini. (2021b). Pengembangan Desain Instruksional Model Inquiry Learning Teintegrasi TPACK Untuk Meningkatkan Kemampuan Pemecahan Masalah. Jurnal Pengembangan Pembelajaran Matematika, 3(1), 1-11. https://doi.org/. http://dx.doi.org/10.14421/jppm.20 21.031-01

Yanti, M., Sudia M., \& Arapu, L. (2019). Pengaruh Model Pembelajaran Mind Mapping Terhadap Kemampuan Berpikir Kreatif matematis Peserta Didik Kelas VIII SMP Negeri 8 Konawe Selatan. Jurnal Penelitian Pendidikan Matematika, 7(3), 7184.

http://dx.doi.org/10.36709/jppm.v7 i3.11375

Yusmin, E. (2017). Kesulitan Belajar Siswa pada Pelajaran Matematika (Rangkuman dengan Pendekatan Metaethnography). Jurnal Visi Ilmu Pendidikan, 9(1), 2119-2136. http://dx.doi.org/10.26418/jvip.v9i 1.24806 